\title{
Employability Skills of Vocational Graduates: Implementation of Curriculum IQF Level 2
}

\author{
Sri Sulistiani, Bambang Yulianto \\ Department of Language and Literature \\ Universitas Negeri Surabaya \\ Surabaya, Indonesia \\ srisulistiani.18008@mhs.unesa.ac.id
}

\begin{abstract}
The Indonesian Qualifications Framework (IQF) regulates the level of competency level 1-9 which juxtaposes, equalizes and integrates between the education sector and the field of job training and work experience. The level of Vocational High Schools/Vocational Islamic Senior High Schools is entered at level 2 which is grouped in the position of operator. One of the efforts to develop the school is through the employability skills program. Employability skills must be possessed by every employee to improve competitiveness and success in increasing productivity and profits. This article is the result of a literature review by reading books developing Vocational High Schools/Vocational Islamic Senior High Schools programs to optimize the employability skills program by offering new ideas that are applicable and provide tangible provisions to enter the competitive workforce. To optimize the employability skills program is carried out through the teaching factory program, professional certification, and the development of DNAInnovators.
\end{abstract}

Keywords-curriculum; IQF; employability skills

\section{INTRODUCTION}

The rapid development of the global world requires individuals as members of society to be ready for the existing revolution. Moreover, the world of education helps prepare the next generation who are able to compete and be competitive in all fields. The development of education is an effort towards better civilization across times. Only those who are competent can compete in the world of global civilization concerning human ability to keep up with the time changes, modernity, and information and technology.

Currently, it is very easy to find a bachelor graduate who applies a work using his vocational diploma. Likewise, there are many scholars of a particular specialization working for different fields, also known as not linear professional works, and more examples of nonconformities. In this context, there is a problem of competence and qualification. Through Law Number 12 Year 2012 [1] and Presidential Regulation Number 8 Year 2012 [2], the IQF is stipulated. IQF is a competency qualification framework that can juxtapose, equalize, and integrate between the fields of education and the field of job training and work experience in a form of granting recognition of work competencies in accordance with work structures in various sectors.
IQF curriculum development along with the preparation of the birth of the Indonesian Gold Generation 2045 and the Industrial Revolution (IR) 4.0 commonly are prepared for the digital era. Data that are usually stored physically and manually migrate to digital data. Existing data is programmed and managed with computer programming languages so that it is more effective and efficient. The impact of digitalization on the changes in social behavior towards various types of work causes disruption. The disruption era is a phenomenon that shows a shift in activities carried out in the real world into cyberspace. This phenomenon raises the existence of many chaos and anti-mainstream living systems. Three literation namely data literacy, technology, and humanity are important for the development of all types of work in the era of the IR 4.0 , so that education must follow this trend. If it does not, then the education might be left behind.

The determination of the IQF in schools is carried out by establishing Curriculum 2013 or Education Unit Level Curriculum (KTSP) 2013 which has competency in attitudes, knowledge, and skills that must be internalized and mastered by students. Graduate Competency Standards applied [3] explains learning with the 2013 curriculum is intended to develop the potential of students to have the ability to live as individuals and citizens who are faithful, productive, creative, innovative, and affective, and able to contribute to the lives of the people, nation, state, and world civilization. Furthermore, in the Minister of Education and Culture Regulation Number 103 of 2014 [4], this learning process also provides opportunities for students to develop their potential to pursue abilities that can increase their attitudes (e.g. spiritual and social), knowledge, and skills for community, nationhood, and the betterment of human life.

Based on the description, this article is the result of a literature review by offering new ideas, what programs are used to optimize the employability skills program? This program aims to meet the demands of the Industrial and Business World who want workers who have adequate competence and are able to compete through program teaching factory, professional certification, and the development of DNA-Innovators. 


\section{METHOD}

This article was the result of a literature review by exploring various relevant and scientifically accountable sources. The results of the literature study were presented descriptively. This article was expected to contribute ideas to improve the quality of education at the Islamic Vocational High School/Vocational level in implementing employability skills programs.

\section{RESULTS AND DISCUSSION}

Legislation regarding curriculum IQF has been launched since 2012, but the optimization of its implementation depends on the readiness of each school. The focus of this article describes the implementation of IQF at level 2 and the implementation of employability skills programs.

\section{A. Curriculum IQF Level 2 for Vocational High School Level}

Revitalization of Vocational High Schools that occupy level 2 of the IQF is expected to have a positive impact on improving the quality of Vocational Schools with two new orientations. First is anticipating the coming of the IR 4.0 with all the disruptive technologies and, second is the orientation of developing the regional potential as a national superiority to create national competitiveness. As we know, Curriculum IQF has 9 levels that describe the qualifications of graduates at every level of education starting from level 1 (basic education) to level 9 (Level 3/S-3). For instance, level 1 to 3 are grouped into an operator position, level 4 to 6 are grouped into a technical or analyst position, and level 7 to 9 are grouped into an expert position.

In regard to Curriculum IQF, there are two essential things contained in this curriculum namely graduate competency (e.g. learning outcome) and performance qualifications. The graduates' qualifications refer to a competency mastery which states their position in the IQF level. Every level of qualification in Curriculum IQF has an equality with learning outcomes generated through education, job training, or work experience. Since the mid of 1990s, the relationship between Vocational and Business World (BW)/ Industrial World (IW) has become one of the main focuses of the Vocational Education development policy in Indonesia.

One strategy to implement the concept of link and match is Dual System Education (DSE) that integrates systematically and synchronously school education and skills mastery programs obtained through direct work in the workforce to achieve a particular level of professional expertise. DSE is a proactive strategy that brings students closer to the world of work. The prospective workforce of vocational graduates is expected to be able to compete at national and international levels.

Along with the development of the IR 4.0 was announced about the Expertise Spectrum of Vocational High Schools/Vocational Islamic Senior High Schools [5]. The Expertise Spectrum is the types of educational programs and signs for implementation, as a reference in opening and developing programs in Vocational Secondary Education. The type of education program or department of expertise opened at Vocational Schools changes and develops according to the needs and development of the era. Schools that implement the IQF curriculum must produce graduates who are able to compete with certain qualification standards.

\section{B. Vocational Graduates' Employability Skills:} Implementation of the Level-2 Curriculum IQF

In the learning process, students are no longer just learning autistic skills, but learning "future content" that is more holistic through innovative learning projects that bridge theory and practice more realistically, with the object of learning the potential advantages of local natural resources. Therefore, education must ensure that future graduates are equipped with 'generic' work skills that are adaptive with a variety of related work environments, for example the ability to manage information, communicate with others, solve problems and prioritize learning [6]. One of the implementation of the IQF at the Vocational High School level is a quality improvement program with employability skills or job skills.

\section{1) Definition of Employability Skills}

Employability skills are the basic skills that every worker must have to use and to adapt to the workplace. The skills must be possessed by every worker to improve competitiveness and success in increasing productivity and profits [7]. Buck and Barrick [8] describe work skills as attributes of employees, in addition to technical competencies, which make them as assets.

The biggest challenge in the world of vocational education is to produce graduates who have academic ability-skills, ability to master special-technical skills, and work-balanced work skills [9]. Sudana [9] explains that vocational graduates can refer to skilled and qualified laborers if they truly master the hard skills and soft skills aspects. Hard skills aspects are technical skills while soft skills are behavioral skills. Hard skills and soft skills are formed through the learning process according to the competence of their skills, both during class hours and outside of school hours. The formation of attitudes that support aspects of student employability skills requires a periodic and continuous and comprehensive process, so that vocational graduates can meet the standards needed by the BW-IW and become professional workforce. Workforce competence regarding work skills is an important element that influences their work [10].

Presents the research document of employability skills that contains reviews and evaluations by answering questions such as (1) what skills and behaviors are most valued by employers in the prospective level employees, (2) why work skills are so important in a diverse or contemporary workplace, and (3) what education practices have been proven effective in providing the skills and behaviors that can be employed by students [8].

In addition, employability skills are also needed in nonformal institutions. Course institutions such as the Center and Career Readiness and Success (CCRS) and the Great Teachers and Leaders (GTL) [11] outline 2000+ employability skills are work skills, attitudes, and behaviors needed to participate and develop in the world dynamic work. Through this course, the leadership of the institution invites and encourages students, 
teachers, parents, employers, workers, community leaders, and the government to use $2000+$ Skills as a framework for dialogue and action. Understanding and applying these work skills will help to enter, survive, and advance in the world of work. Therefore, work skills refer to general skills needed to succeed in the labor market at all levels of employment and sectors.

$2000+$ work skills, which can be taught through the education system and workforce development, are divided into three broad categories namely effective relationships, workplace skills, and applied knowledge. Define work skills as the skills needed not only to get a job, but also to develop in a company to reach one's potential and contribute successfully to the company's strategic direction [12]. Furthermore, identify the work skills framework by combining eight main skills namely (1) ability to communicate, (2) ability to work together, (3) problem solving skills, (4) company initiatives and skills, (5) planning and organizing skills, (6) selfmanagement skills, (7) learning skills, and (8) technological skills [12]. As a formal method provides a framework for bringing a large amount of relevant information to be coherently borne, this is an achievement that is beyond the reach of informal methods. However, both are not exclusive to each other and decision makers can consider quantitative predictions as only one of a number of sources of information that must be taken into account. When it comes to generic skills or work eligibility, the level of quantitative uncertainty increases. General skills are generally not strictly defined as job-specific skills, and hence their economic role cannot be easily generated by ordinary methods of surveying market participants. Students can finally identify that Problem-Based Learning (PBL) allows them to develop work skills in addition to the application of content knowledge [13].

In accordance with Minister of Education and Culture Number 20 Year 2016 concerning Graduates' Competency Standards [14], a graduate from Vocational School has at least competencies that are viewed from three dimensions namely attitude, knowledge, and skill dimensions. In the skill dimension, vocational graduates must have the ability to think and act effectively and creatively in the abstract and concrete realm as the development of what must be studied in school independently. Organization for Economic Co-operation and Development (OECD) identifies four generic competencies in employability skills namely multifunction that is relevant across many fields of competence, and relevant demands of mental complexity assuming a mental anatomy that includes active and reflective approaches to life and multi-dimensional that consists of know-how, analytical, cultural and communication skills, and communication [9].

Employability skills are considered very important because each job requires initiation, flexibility, and one's ability to handle different tasks. This means that the skills possessed by workers do not have to be specific, but should be more service-oriented and more importantly have professionally integrated social skills. Employers, employees and educators assume different levels of importance for employment skills, and this creates a gap in employment skills [15].

\section{2) Implementation of Employability Skills}

The development of the global economy, information, and communication technology requires a level of competence that is able to quickly anticipate any changes and developments, so that the demands of work skills continue to grow as well. In addition, there is a need to consider curriculum redesign with work abilities that are fundamental to the curriculum, where students can identify and explicitly link to their learning activities with desired graduate competencies [16]. Hanafi [9] explains what is included in employability skills namely (1) basic skills which include reading, writing and arithmetic, (2) interpersonal skills including communicating and working in teams, and (3) self attributes including the ability to learn and how to deal with changes that always occur in society. Employability skills as relevant skills to various fields of work and professions can be done in various ways, among others:

\section{a) Teaching Factory Program}

Following up on Presidential Instruction Number 9 Year 2016 concerning Revitalization of Vocational High Schools [17], the Ministry of Education and Culture has made the Inpres as fundamental to reorganizing vocational education in Indonesia. The Inpres provides an affirmation of the importance of Vocational Schools in preparing skilled and characterized human resources in order to fill the opportunities for labor in development which drives the acceleration of Indonesia's progress.

Related to the Presidential Instruction, the first is carrying out to revitalize the teaching factory program which has been introduced in Vocational Schools since 2000 in a very simple form namely the development of production units that has been implemented in Vocational Schools. The Directorate General of Primary and Secondary Education Management states that the effort to accept vocational graduates in BW-IW can be done by (a) strengthening adaptive abilities which include applied mathematical abilities and applied science, (b) strengthening entrepreneurship skills, (c) strengthening abilities using national and international languages, (d) strengthening basic ICT skills, and (e) implementing teaching factories.

Teaching factory is a development of dual system education, namely Competence-Based Training (CBT) and Production-Based Education and Training (PBET) implemented by Vocational Schools. Teaching factory learning is a learning concept in production / service based Vocational Schools that refers to standards and procedures that apply in the industry and is implemented in an atmosphere like what happens in industry [18]. This is in accordance with the characteristics of vocational education as mentioned by Herminarto [18] namely (1) preparing students to enter employment, (2) relying on the needs of the workforce "demand-market-driven", (3) mastering competencies needed by the world of work, (4) succeeding "hands on" or work performance, (5) having close relations with the world of work, (6) being responsive and anticipatory towards technological progress, (7) learning by doing and hands on 
experience, and (8) requiring greater investment and operational costs than general education.

The basic principles of vocational teaching factories in implementing teaching factory programs are (1) the integration of work experience into the vocational curriculum, (2) preparing and designing all equipment and materials as well as educational actors to carry out the production process with the aim of producing products (e.g. goods or services), (3) a combination of production-based and competency learning, (4) vocational students must be directly involved in the production process of production-based learning, so that their competencies are built based on production needs. Production capacity and product type are the main keys to the successful implementation of production-based learning [18]. Teaching factory is a model of learning activities that is very effective and efficient. Some basic values that must be developed to support the readiness of the implementation of the teaching factory include a) sense of quality providing basic skills to students related to objective standards of quality, b) sense of efficiency equipping students with the ability to work efficiently to create common practices carried out by industry, c) sense of creativity and innovation to teach students to work creatively and innovatively, train problem solving skills as a measure of creativity, and look for new opportunities in the industry such as products, designs, and so on.

\section{b) Professional Certification}

Professional certification institutions with the name of the Professional Certification National Agency are independent institutions formed based on Government Regulation Number 23 of 2004, which then changes with Government Regulation Number 10 of 2018 [19] concerning the provisions of professional certification.

Related to this Professional Certification National Agency, the IQF provides a basis through better worker mobility for better national, regional, and international integration. This will provide a mechanism to develop the quality of the Indonesian workers' ability to compete for jobs in other countries in ASEAN and in any country, according to their training and experience. For the ASEAN level, presents the ASEAN Qualifications Reference Framework (AQRF), which allows comparison of educational qualifications across ASEAN Member States (AMS) [9]. The objectives of the AQRF include (1) supporting the recognition of qualifications, (2) encouraging the development of a qualification framework that can facilitate lifelong learning, (3) encouraging the development of national approaches to validate learning obtained outside formal education, (4) promoting and encouraging student's education and mobility, (5) supporting worker mobility, (6) increasing understanding of the qualification system, and (7) promoting a higher quality of qualification system. Revitalization is carried out with two main strategies. The first scenario is perfecting and strengthening vocational schools with demand-driven models as well as changing the supply-driven model that has been going on so far with quality standardization. The main characteristics of vocational education and training prioritize the job-based learning approach. School design is developed from the needs and recognition of the business and industry.
The second scenario is to develop vocational schools and creative training with life-based learning models as alternative education. Learning at Vocational High School emphasizes a potential based approach to real life nature. This model allows the growth of creative schools in accordance with the superiority of the potential of the region.

AQRF aims to support the establishment of the ASEAN Community and specifically through the process of achieving objectives (1) free flow of skilled labor through harmonization and standardization and (2) The 2015 ASEAN Socio-Cultural Community (ASCC) Blueprint seeking "to build the national skills framework as an additional approach towards ASEAN skills recognition framework" [9]. AQRF is an initiative that is in line with the goals of the ASEAN Charter to develop human resources through closer collaboration in education and lifelong learning to empower the ASEAN community and to strengthen the ASEAN Community.

c) Development of Innovator DNA (Deoxyribonucleic Acid) Models

The Technology, Entertainment, and Design (TED) conference developed into a provocative forum to generate powerful new ideas, when intelligent individuals with diverse backgrounds are connected in the same mindset to change the world. To answer the global challenges [20], develop "The Innovator's DNA" which enhances cognitive skills encompassing associational thinking, questioning, observing, networking, and experimenting. Most of people think that creativity is a full cognitive skill that occurs in the brain. The critical insight of our research is that a person's ability to produce innovative ideas is not only a function of the mind, but also a function of behavior. Therefore, it means that if we change our behavior, we can increase our creative impact. Furthermore, developed this study that included four types of innovators namely start-up entrepreneurs, entrepreneurial companies, product innovators, and process innovators [20]

In an effort to build innovative creativity, explain in detail the five skills that can be mastered by anyone to improve their own ability to become innovative thinkers such as by asking: (1) Are I good at generating ideas innovative business? (2) Do I know how to find innovative people for my organization? (3) Do I know how to train people to be more creative and innovative? (4) How do I think outside the box? And (5) How to be creative? The slogan think different allows innovators to think differently and boldly try new things to become an innovative personal [20].

DNA Innovators are carried out by strengthening the ability to ask questions and identify skills such as observing, building networks, and experimenting and trying to practice to overcome the challenges of innovation. Each of these skills is done by involving as many teams as possible in any discovery skills that are being worked on (e.g. observing, building, or experimenting) as a solution to challenge. Finally, involved in brainstorming sessions to practice communicating and socializing is necessary.

The mystery when people practice DNA Innovator skills regularly could be the habits. This requires time and selfdiscipline by starting with realistic expectations and activate 
the time to improve your discovery skills. Most importantly, personal development efforts will send serious signals to the team and organization about how high the ranking of innovations in a priority scale. The results of the study show that observing, networking, and experimenting correlates significantly with starting new innovative businesses.

Optimizing employability skills as a form of IQF curriculum implementation at level 2 through teaching factory, professional certification, and DNA Innovators is expected to provide adequate provisions for students to enter the world of competitive professional work in accordance with established standards. This is urgent to do, because Vocational High School / Vocational Islamic Senior High Schools graduates need proof of recognition of their competencies so they can be accepted in the expected workforce.

\section{CONCLUSION}

Implementing the IQF curriculum based on the development of industrial revolution 4.0 at level 2 for Vocational school level can be conducted by strengthening Employability Skills. Vocational School is one form of formal education unit that organizes vocational education at the secondary education level. Vocational education prepares graduates to work in certain fields. To be a qualified and competent workforce in the BW-IW fields, it is necessary to provide employability skills, a set of skills that allows a person to get a job or can continue to work including personal skills, interpersonal skills, attitudes, habits, and behaviors Strengthening employability skills is done by (1) teaching factory programs, (2) professional certification, and (3) developing DNA Innovators. Through these programs, it is expected that the goal of revitalizing learning in Vocational Schools can be achieved by producing graduates who are ready to work and compete on a national, regional and international scale.

\section{REFERENCES}

[1] Government of the Republic of Indonesian, Law Number 12 Year 2012 concerning on Higher Education. Jakarta, 2012.

[2] President of the Republic of Indonesia, Presidential Regulation Number 8 Year 2012 concerning on establishing the Indonesian National Qualification Framework (INQF). Jakarta.

[3] Minister of Education and Culture of the Republic of Indonesia, Minister of Education and Culture Number 54 Year 2013 concerning on Graduate Competency Standards. Jakarta, 2013.

[4] Minister of Education and Culture, Minister of Education and Culture Regulation Number 103 of 2014, concerning learning process. Jakarta, 2014.

[5] Directorate General of Primary and Secondary Education, Regulation of the Directorate General of Primary and Secondary Education Number 06 / D.D5 / KK / 2018 dated June 7, 2018 concerning on
Expertise Spectrum. Jakarta, 2018.

[6] M. Smith, D. Mike, and C. Kathryn, "Graduate Employability: Student Perceptions of PBL and its Effectiveness in Facilitating their Employability Skills," 2013. [Online]. Available: http://community.dur.ac.uk/pestlhe.learning/index.php/pestlhe/article/viewFile/93/108. [Accessed: 27-Mar-2019].

[7] M. R. Bloom and K. Kitagawa, "Understanding Employability Skills," 1999. [Online]. Available: http://www.acc.ca/wpontent/uploads/archive. [Accessed: 02-Apr2019].

[8] K. Cotton, "Developing Employability Skills," 1999. [Online]. Available:

https://educationnorthwest.org/sites/default/files/DevelopingEmployabi litySkills.pdf. [Accessed: 29-Mar-2019].

[9] M. (Ed) Herdyka, Employability Skills Lulusan SMK dan Relevansinya Terhadap Kebutuhan Dunia Kerja. Jakarta: Direktorat Pembinaan Sekolah Menengah Kejuruan Direktorat Jenderal Pendidikan Dasar dan Menengah Kementerian Pendidikan dan Kebudayaan., 2018.

[10] M. Abas-Mastura and O. A. Imam, "Employability Skills and Task Performance of Employees in Government Sector," Int. J. Humanit. Soc. Sci., vol. Vol. 3, no. No. 4 [Special Issue - February 2013, 2013.

[11] CCRS Center and GTL Center, "Integrating Employability Skills: A Framework for All Educators," American Institutes for Research (AIR), 2016. [Online]. Available: https://ccrscenter.org/sites/default/files/EmployabilitySkills_Handouts.pdf. [Accessed: 29-Mar-2019].

[12] A. Esposto and G. A. Meagher, "the Future Demand for Employability Skills : a New Dimension To Labor Market Forecasting in Australia," Commonw. Aust., no. April, 2015.

[13] L. Martin and K. Bill, "Incorporating Problem-Based Learning Strategies to Develop LearnerAutonomy and Employability Skills in Sports Science Undergraduates," Journal of Hospitality, Leisure, Sport and Tourism Education Vol. 7, No. 1. ISSN: 1473-8376, 2008. [Online]. Available: https://www.researchgate.net/-profile/Karen Bill/ publication/26579078. [Accessed: 30-Mar-2019].

[14] Minister of Education and Culture, Minister of Education and Culture Number 20 Year 2016 concerning Graduates' Competency Standards. Jakarta, 2016.

[15] I. Sarfraz, Diana Rajendran, and C. Hewege, "An exploration of global employability skills: a systematic research review," Int. J. Work Organ. Emot., vol. Vol. 9, No, 2018.

[16] A. D. ROWE and KARSTEN E. ZEGWAARD, "Developing graduate employability skills and attributes: Curriculum enhancement through work-integrated learning," Asia-Pacific J. Coop. Educ., no. Special Issue, 2017, 18(2), pp. 87-99, 2017.

[17] President of the Republic of Indonesia, Instruction of the President of the Republic of Indonesia Number 9 Year 2016 concerning on Revitalization of Vocational High Schools. Jakarta, 2016.

[18] T. Haryanti and D. (Ed.)., Tata Pelaksanaan Teaching Factory. Jakarta: Direktorat Pembinaan Sekolah Menengah Kejuruan Direktorat Jenderal Pendidikan Dasar dan Menengah Kementerian Pendidikan dan Kebudayaan, 2017.

[19] G. Regulation, Government Regulation Number 10 Year 2018. Jakarta, 2018.

[20] J. H. Dyer, H. B. Gregersen, and C. M. Christensen, "The Innovator's DNA The Idea in Brief," Harv. Bus. Rev., no. December, pp. 1-9, 2011. 